\title{
Greening campus experience: moving towards living laboratory action plan
}

\author{
Wahid Omar ${ }^{1}$, Azlan Abdul Rahman ${ }^{2 *}$, Mohd Fadhil Md Din ${ }^{3}$, Shazwin Mat Taib ${ }^{3}$, Santhana krishnan ${ }^{3}$, Irina Safitri Zen ${ }^{4}$, \\ Norhisyam Hanafi ${ }^{3}$ \\ ${ }^{1}$ Chancellor Office, Universiti Teknologi Malaysia, 81310 Johor Bahru, Johor, Malaysia \\ ${ }^{2}$ Office of Deputy Vice Chancellor (Development), Universiti Teknologi Malaysia, 81310 Johor Bahru, Johor, Malaysia \\ ${ }^{3}$ Campus Sustainability Office, Universiti Teknologi Malaysia, 81310 Johor Bahru, Johor, Malaysia \\ ${ }^{4}$ Faculty of Built Environment, Universiti Teknologi Malaysia, 81310 Johor Bahru, Johor, Malaysia
}

\begin{abstract}
Sustainability is a growing priority for higher education institutions around the world. Universiti Teknologi Malaysia (UTM) through UTM Campus Sustainability Office ready to transform the campus as platform to inculcate the sustainability mind set of young people through education and empowering them to continue living the values in the future as stated in Transformasi Nasional 2050 (TN50) development plan. In 2010, among the first institution supporting UI GreenMetric auditing, UTM was positioned at rank 85, and then gradually improving the performance to position ourself to rank 66 in 2017. To boost this effort, sustainability elements have been implemented in Universiti Global Plan III (2018-2020) and UTM Master Plan 2017-2037. One of the main strength of UTM in UI GreenMetric evaluation components is Setting and Infrastructure that incorporates environmental and social considerations in addition to the traditional cost, time and quality. Improvement through transnational researches which is under Water and Energy Nexus projects such as biomass utilization and groundwater projects are escalating the efforts. For developing more robust approach, Sustainable Development Goals (SDG) has been incorporated in to six Living Labs (LL) initiatives. Positioning in global branding, integration across campus and regional level networking was aimed to leverage currents assets into further opportunities for research, teaching and institutional development.
\end{abstract}

\section{Approach to sustainability}

Universiti Teknologi Malaysia (UTM) as a leading innovation-driven entrepreneurial research university in engineering science and technology taking sustainability seriously by incorporate Sustainable Development Goals (SDGs) and Education for Sustainable Development (ESD) thorough a comprehensive framework of research integration, educational and operational subsidiary was constructed to balance of academic and non-academic implementation.

\subsection{Introduction}

The role of the university in advancing sustainability development has been widely recognized and the college campus is seen as offering an ideal setting for exploring and practicing sustainability. In universities, sustainability presents an opportunity to make education more problems based, more interdisciplinary and more applied [1]. Some value its broad based international political clout in bringing environmental issues back to the forefront. Others see in sustainability an opportunity to reflect on the role the university has to play in society and in the health and lifelong learning of employees and students. A sustainable university campus should be a healthy campus environment, with a prosperous economy through energy and resource conservation, waste reduction and an efficient environmental management, and promotes equity and social justice in its affairs and export these values at community, national and global levels [2].

\subsection{Resolve for future sustainable campus}

The university determination towards sustainability at campus reflected through detailed planning and UTM sustainable policies (UTM-P). Totally there are fifteen policies (UTM-P1 to UTM-P15) was introduced and being executed for sustainable practice inside campus [3]. Sustainability already incorporated into University Global Plan phase I and II from 2012-2017. From position 85 in 2010 UI Greenmetric ranking, UTM elevates by leaps and bound to positon 66 in 2017. Based on the excellent achievement, UTM has won two awards in 2017: Kelestarian Kampus Hijau Universiti Awam Malaysia (Malaysia Public University Green Sustainable Campus) from Ministry of Energy, Green Technology and Water (KeTTHA) and also Diamond Recognition Certificate LCCF Award Recognition Ceremony \& Low Carbon Cities Framework (LCCF) Implementation Sharing Session [4].

To step up the game, UTM have executed the University Global Plan phase III (2018-2020) which 
consist of introduction of in-campus electric bus project, development of database of national and international sustainability awards and enhance "Waste-to-Wealth", "Recycle, Reuse, Reduce (3R)" programs. Universiti Global Plan III (2018-2020) is developed based on six main key focus areas namely: 1. Excellence in Learning and Teaching, and Transformative Campus Experience, 2. Research Excellence, Industry and Community Engagement, 3. Sustainable Campus, Infrastructure, Information and Communication (ICT) System, 4. Talent Transformation, Governance and High-Performance Delivery, 5. Advancement and Business Development for Financial Sustainability, and 6. Global Prominence

and Branding. The six main focus areas are translated into Strategic Objectives (SO) and Key Amal Indicators (KAI) of various initiatives and programs to be implemented. The success of PGU Phase III is dependent on four core values: Integrity, Synergy, Excellence and Sustainability towards universal wellbeing that strives for the good of the stakeholders, mainly the community and industry. The third phase also inculcates volunteerism among staff and students on its implementation. UTM Master Plan 2017-2037 for future administrator guideline $[5,6]$.

\section{Setting and infrastructure of campus}

A well-planned campus landscape supports the university's commitment to sustainability by enhancing ecosystem services such as clean water and air, regulating climate, soil building and erosion control, habitat enhancement, and improvement of human health and well-being. These benefits extend to the community surrounding the campus as well. UTM aims to develop an excellent infrastructure through the adoption of sustainable planning, design and construction principles. The basic setting and infrastructure information of the Universiti Teknologi Malaysia (UTM) towards sustainability is represented as Table 1. UTM Main campus is built in an 1145 hectare of land and total up to 612 buildings which consists of 14 faculties, 13 hostels, and 6 administrative buildings.

Table. 1. Setting and infrastructure at UTM.

\begin{tabular}{|l|l|}
\hline Criteria & $\begin{array}{l}\text { Setting \& } \\
\text { Infrastructure }\end{array}$ \\
\hline Total main campus area & $11,440,000 \mathrm{~m}^{2}$ \\
\hline $\begin{array}{l}\text { Total main campus smart building } \\
\text { area }\end{array}$ & $128,025 \mathrm{~m}^{2}$ \\
\hline $\begin{array}{l}\text { Total area on campus covered in } \\
\text { vegetation in the form of forest }\end{array}$ & $39 \%$ \\
\hline $\begin{array}{l}\text { Total area on campus covered in } \\
\text { planted vegetation }\end{array}$ & $32 \%$ \\
\hline $\begin{array}{l}\text { Total area on campus for water } \\
\text { absorption besides forest \& planted } \\
\text { vegetation }\end{array}$ & $29 \%$ \\
\hline
\end{tabular}

UTM comprise a large-scale type of building complex development which making UTM responsible to a huge challenge in order to manage the whole resources and facilities with 33,000 populations of staffs and students. The total ground floor and building area comprises of $426,748.68 \mathrm{~m}^{2}$ and $1,132,403.95 \mathrm{~m}^{2}$, respectively. The campus maintains the $39 \%$ of green area in form of forest and $32 \%$ covered in planted vegetation. Total main campus smart building area consists of $128,025 \mathrm{~m}^{2}$. UTM emphasises respect for natural resources, adapting to climatic conditions, and setting new standards for building performance through an environmentally-conscious setting.

\subsection{UTM eco-home project}

UTM Eco-Home is a project (Fig.1) that was initiated from UTM involvement in Solar Decathlon China 2013 (SD China 2013). The main purpose of an Eco-Home is to help disseminate, as well as become a showcase to all the technologies engaged for a green and sustainable home cum small office development. The development is to provide an exhibition space for UTM research products; to promote UTM Eco-Home to the public as an intelligent sustainable home; and to create medium for related researchers to conduct research works at this location. UTM Eco-Home designed and constructed to be a showcase of sustainable single storey threebedroom bungalow located at UTM main campus in Skudai, Johor Bahru. The building is also an experimental and research venue for sustainable, green, low $\mathrm{CO}_{2}$, low energy, smart building control, energy efficiency, building technologies and construction technique. One of the main objectives of the building is to demonstrate sustainable solutions in the design, construction and operation. That includes thermal comfort, low energy demand and low or zero carbon emissions building. Through this Eco-home project, the implemented UTM policies (UTM-P) include adopting green building and infrastructure design through a clear sustainable development framework to achieve cost effectiveness (UTM-P-1), optimising university assets and sustainable business opportunities to promote economic viability (UTM-P-2) and achieving efficiency in operational management of resources, facilities (UTM-P-3), and promoting low carbon practices among campus community (UTM-P10).

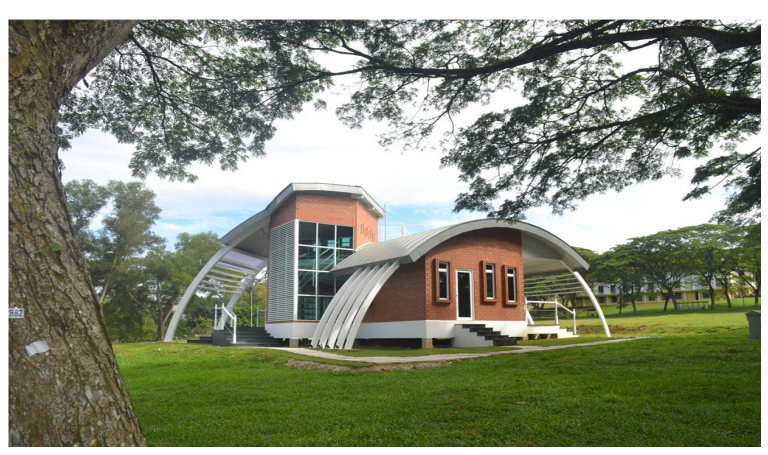

Fig. 1. UTM eco home. 


\section{SDGs initiatives reflection in sectoral action plan}

Concept of Living Laboratories (LL) can be interpreted and used as a human-centric research and development approach. UTM LL approach not only focuses on involving students in development process, it also strives to facilitate the interaction among other relevant stakeholder, such as academia, researcher, and administrative personnel (Fig. 2). This interaction will generate a showcase of campus society as a translator of sustainable development and allows more creative and innovative conducive teaching and learning environment. A university would operate as a fully integrated community that models social and biological sustainability itself. In many cases, people think on education, research, operation as separate activities but they are not actually. Because students learn from everything around them, these activities form a complex of experience and learning. It is an interdisciplinary, trans-disciplinary and problem-based approach. The students need to overcome this larger, extensive form of learning, education experience must reflect on intimate connection among curriculum and research; understanding any negative ecological and social footprint of the institution and improve local and regional communities to healthier and environmental sustainable. Therefore, the concept of LL is good approach to enhance the sustainable development in UTM. The currently six LL in our campus are LL1 Sustainable Arcade, LL2 Green office, LL3 Sustainable Energy Management, LL4 Bio-Recycling Centre, LL5 Green School and LL6 Green Community. All of the initiatives direct and indirectly reflect few Sustainable Development Goals initiatives that have been ruled out by United Nations (UN).

\subsection{LL1 sustainable arcade}

It is one of strategic key initiatives of UTM to promote Green, Healthy and Safety Practice to the consumers and food operator in food arcade. It has main objective to reduce the waste generated in arcade (solid waste, food waste), practice recycling and resource recovery which reduce the carbon emission generated. The benefits not only contribute to the environment but also the campus society as a whole in combating zero hunger (SDG 2), good health and wellbeing (SDG 3) and responsible consumption and production (SDG 12).

\subsection{LL2 green office}

Conventional office provides lots opportunities for green practices. From minimize the use of the paper, adjusting the office lighting system to let the natural sunlight enter the room, recycle the used computer, ink toner and cartridge until the selection of electronic that save the energy. Affordable and clean energy (SDG 7), climate action (SDG 13) and responsible consumption and production (SDG 12) are applied SDGS on this effort.

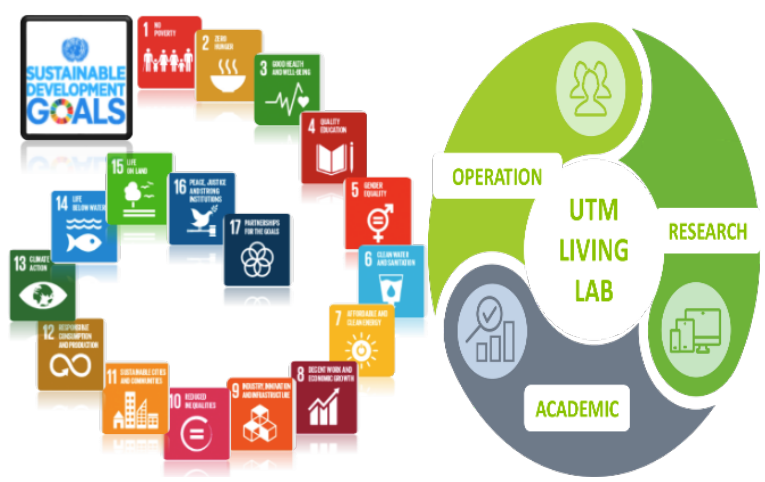

Fig. 2. UTM key living lab initiatives \& SDGs.

\subsection{LL3 sustainable energy management}

Sustainable Energy Management (SEM) is a Universitywide commitment program. The University will strive to efficiently manage the consumption of energy in a manner that is consistent with providing a conducive and sustainable campus environment for teaching, learning, research and intellectual development. Among SDGs served on this initiative are sustainable cities (SDG 11), climate action (SDG 13), responsible consumption and production (SDG 12) and communities and affordable and clean energy (SDG 7).

\subsection{LL4 bio recycling centre}

Food waste and kitchen waste from food arcades around the campus will be collected and mixed with shredded garden waste. Other conditioners and Effective Microbe (EM) will be employed to effect decomposition of the organic waste under controlled conditions. The composted products will be further treated and converted into soil enhancer, compost fertilizer or animal feeds. Chemical and physical analysis will be carried out to characterize the raw intermediates and final products of the recycling process (Fig. 3). These initiatives reflect good health and well-being (SDG 3) and responsible consumption and production (SDG 12).

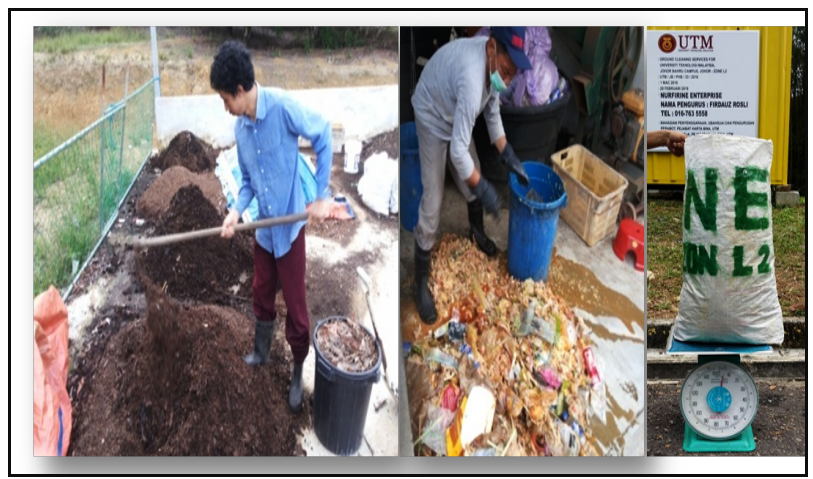

Fig. 3. Organic waste recycling facility in UTM. 


\subsection{LL5 green school}

Green school is one of the sustainable campus initiatives which aim to educate high school and primary school students regarding sustainability concepts and issues. With various platform such as workshop, exhibition and sustainable activity, UTM experts reaching out to young generation building the capacity on the importance of sustainability. It's expected these pool of youth can act as ambassador communicating the concept and importance of sustainability at large and live a positive life appreciating the three sustainable element in the future, which is Human, Nature and Economy. Quality education (SDG 4), strong institution (SDG 16) and partnership for the gaols (SDG 17) are SDGs initiative can be fulfilled by this action. Encouraging activities that appreciate the existing natural environment (UTM-P14) is the element targeted by this initiative and promoting active and healthy lifestyle within the secure environment (UTM-P15).

\subsection{LL6 green community}

UTM contributing back to the community through LL6 Green Community which aim to help the society problems by providing a sustainable solution. Besides helping the community by using sustainable approach, green community initiative is also at the same time try to educate the society regarding the importance of sustainability environment and several issues related to it such as carbon and waste management. Various initiatives can cover various aspect of SDGs elements but mainly supporting by partnership for the gaols (SDG 17). The UTM-P components are maintaining healthy balance between developed and green areas to achieve campus eco system vitality (UTM-P8), augmenting the conservation of wetland features to support habitat and recreational water activities (UTM-P9).

\section{Collaboration showcases}

\subsection{Sustainable Energy Management Program (SEMP)}

One of the successful achievements of UTM sustainability initiative is the Sustainable Energy Management Program (SEMP) which champion by the energy management group. The group is the unique combination of academic researchers which involves several faculties such as chemical engineering, electrical engineering, professionals and the operational staffs of Office and Asset Development (PHB). This program applies the holistic approach of effective and sustainable energy consumption and management which covers the inclusions of organizational structures and provides campus as a living lab. It is estimated that the renewable energy production inside campus is $81 \mathrm{KW}$ as solar power. Concurrently, the ratio of renewable energy production towards total energy usage per year is $40 \%$ -
$60 \%$. The programs apply the holistic approach of effective and sustainable energy UTM was officially awarded the Energy Management Gold Standard (EMGS) 3rd Star rating under the ASEAN Energy Management (AEMAS) in 2016. Based on the comparison of energy usage in 2009, which is the benchmark year used for the UTM Sustainable Energy Management Program (SEMP), there has been a total saving of 42.0 million $\mathrm{kWh}$ or RM21 million until April 2017. Some of the initiatives taken by the SEMP team to reduce Greenhouse gas (GHG) emission includes retrofitting the air-conditioning system by implementing variable refrigerant volume (VRV) in many faculties and buildings, lighting retrofits, which included de-lamping and installation of high efficiency $\mathrm{T} 5$ and super T8 lights, maximum demand management which involves shifting loads so as to reduce maximum demand on capitalizing off-peak tariff rate (OPTR) discount, utilizing its in-house Online Energy Billing and Management System (EBMS) to communicate and provide up-to-date information to all stakeholders on the campus. Other that, key elements in the formulation of policies and guidelines adopted at UTM to support energy-saving conservation such as ensuring the use of air-conditioner is at the setting rate that has been specified according to the needs of the room and weather. Air temperature setting recommendations are between $24-26^{\circ} \mathrm{C}$; Air conditioner should be switched off for one hour beginning the lunch-hour between 13:00 and 14:00 daily; Indoor lighting or room may use natural lighting if the lighting rate exceeds $40 \%$; Minimize the use of printed papers and ordinary meetings using a variety of printed materials; Using tumbler bottles or multi-purpose food containers in the office to reduce dependency on plastic bottles or plastic containers; All existing and constructed buildings at UTM should at least encourage and implement Smart Building and Green Building features such as devices and system of rainwater harvesting, energy and water conservation tools, green planting and etc. Encourage staff involvement in volunteerism planning related to energy conservation initiatives and $\mathrm{GHG}$ emission reduction commitments; Diversify healthy and vibrant lifestyle activities by practicing cycling, walking and strolling cultures instead of using vehicles and elevators. The implemented UTM-P segments are UTM-P10 and instilling integrity and ethical values through volunteerism and continuous commitment at all levels of the community (UTM-P13).

\subsection{Food Waste Recycling Program (FWRP)}

UTM leading by Office of Asset and Development (PHB) is promoting the Bio Recycling Centre to transform all organic waste into valuable products to promote the sustainable and environmental-friendly practices and various activities/programmers related on waste management towards Zero Waste Program. Most of the activities are encouraging behavior, motivation and awareness on reducing the wasted materials to be dumped at the landfills, which is currently the capacity 
of organic waste (mainly food wastes) occupied up to $55 \%$ of the total component in UTM. It is estimated from 140 arcades around campus could produce nearly two tons of food waste every day, which is the most difficult way to handle it by limited number of staff. Some of practices for the easiest way of separation at sources such as differentiate between organic and non-organic wastes in your plates/food container before throw in the bins; All contractor and catering unit inside UTM must allow the proper bins, in order to separate the food waste and non-food waste to ensure proper services by the Waste Unit, UTM; Ensure the bins at the building/section must equipped with the covered bins; Must alert the sticks/tissue and other related matters which always treated as non-organic features in our plates/food container; Never use plastic bag/straw in the same plates/food container to make sure we are not disposing it together; Always promote to other members on reducing wastes and separation at source campaign; and the concept of $3 \mathrm{R}$ which is only useful for mostly of the recycling part. The Implemented UTM-P elements are eliminating non-biodegradable food and beverage packaging (UTM-P11) and promoting community spirit and enhancing the quality of the life, responsive to local and global context in harmonious and conducive environment (UTM-P12).

\subsection{Water Sustainability Program (WSP)}

UTM has a clear vision and commitment towards the improvement of the policy and guidelines on sustainable water and water resources. Some of initiatives are; clean water sources such as Lata Jernih in Recreational Forests inside UTM campus are preserved and kept of pollutionfree; All of the catchment area of the upstream and a number of fringe forests around UTM will be targeted to reduce the risk of contamination of suspended matters; All units in UTM are encouraged to use rainwater harvesting by installing wire shelf divider mosquito's breeds. Water usage is for the purpose of cleaning and urban farming spraying/fumigation available around the Office building; The use of tap water must be minimized with water saver tools installation, whether in the home or in the main piping building/laboratory unit; Stringent care and awareness about water resource rivers and lakes in the vicinity of UTM will be given to the added value, especially involving biodiversity, prevent water pollution and recreational/leisure; Exploration of groundwater are encouraged with additional information about the level of hygiene and safety to users; and use of nonsustainable detergents and soaps are not encouraged in the kitchen, and floor-type. The implemented UTM-Ps are enhancing sustainable consumption of available resources (Water and Energy) (UTM-P5), minimizing waste and pollution through effective waste management (UTM-P6), and introducing more local flora and fauna to protect and enrich biodiversity (UTM-P7).

\section{Conclusions}

Concept of sustainable campus is relatively new in Malaysia, and several public universities are still at the infant stage in adopting and implementing the sustainability in campus. The institutionalization of campus sustainability involves educational and awareness campaign, dialogue, series of meeting in identifying the target, establishes the system, mechanism and Key Performance Indicators (KPI's). The processes at the same time coupled with the Living Lab approach which allows the contribution three different groups; academic, students and professional and administrative groups of campus sustainability contributes to the campus sustainability campus contributes to the campus sustainability initiatives, efforts and projects. Apparently, the planning and implementation of these initiatives should be phased and prioritized accordingly so that they can affect optimally on sustainability in campus operations. There are various initiatives and sustainable practices that can be adopted and implemented by the top management to ensure that universities operate in a sustainable manner. However, more focus and attention should be given to the initiatives that can give positive impact on the environment, economic and social aspects of the campus community.

Acknowledgements. The authors would like to acknowledge the efforts and contribution of Pejabat Harta Bina, INSTEG group, Landscape Unit, Electrical Unit, Office of Vice Chancellor and Office of Deputy Vice Chancellor (Development).

\section{References}

1 O. Saadatian, K. B. Sopian, E. Salleh, Sustainable Cities and Society, Adaptation of sustainability community indicators for Malaysian campuses as small cities, 6, 40-50 (2013).

2 I. S. Zen, R. Ahamad, \& W. Omar, Jurnal Teknologi. The development and measurement of conducive campus environment for Universiti Teknologi Malaysia (UTM) of campus sustainability, 68(1) (2014).

3 http://www.utm.my/sustainable/our-policy/.

4 K. Tenaga, \& T.H. Air, Low carbon cities framework \& assessment system, ISBN-978-9675893-06-3. (2011).

5 UTM Sustainability Report, UTM press, Towards Low carbon campus, ISBN-978-967-0194-43-1. (2013).

6 R. Zakaria, E. Aminudin, UTM press, Sustainable development campus, ISBN-978-983-52-1478-3 (2017). 